\title{
Gender-based leadership perceptions and preferences of Generation Z as future business leaders in South Africa
}

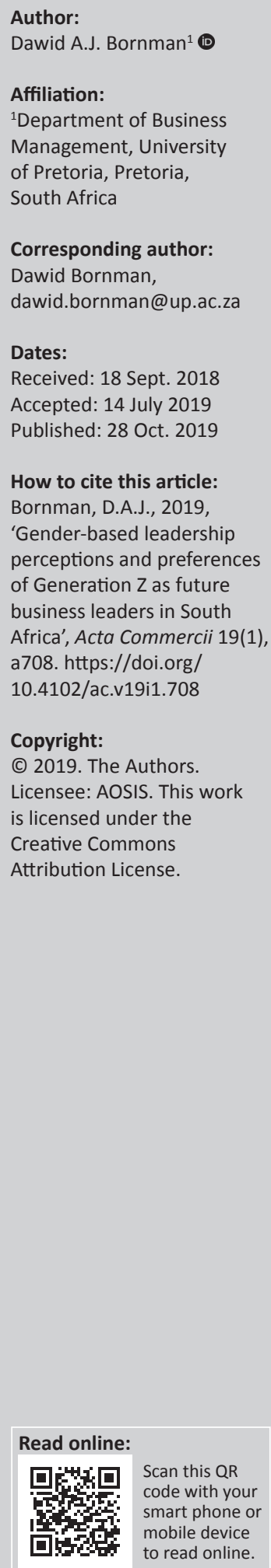

Orientation: Given South Africa's vast diversity, there is little clarity surrounding the most prominent leadership style amongst young male and female (i.e. Generation Z, born between 1995 and 2015) potential leaders.

Research purpose: To investigate the perceptions of Generation Z male and female undergraduate business management students at a tertiary institution in South Africa, towards leadership and its link to gender specific leadership traits.

Motivation for the study: This study is vital as the importance of gender equality and the fair distribution of organisational opportunities are increasing, and due to undergraduate business management students forming part of Generation $\mathrm{Z}$ and being the next generation of possible business leaders.

Research design, approach and method: A self-developed questionnaire by the author was distributed to 469 students, and the final realised sample included a total of 320 usable questionnaires. After a comparative descriptive data analysis, SPSS statistical software was utilised to conduct a Wilcoxon's signed rank test, a Mann-Whitney U test and a KolmogorovSmirnov test for normality, respectively of the study's formulated hypotheses.

Main findings: Male and female Generation $Z$ students favour transformational leadership over transactional leadership, and both gender groups perceive feminine traits as more important for a business leader to exhibit. This contradicts previous research findings where masculine traits were perceived as more important for business and leadership success.

Practical/managerial implications: As transformational leadership has been most frequently cited in literature as the prominent and successful leadership style of the 21st century, all leadership education development should encourage future leaders to develop a transformational leadership style while implementing the inclusion of the feminine trait theory.

Contribution/value-add: These findings help determine which leadership style is favoured by potential future leaders (i.e. Generation Z) at a higher education institution in South Africa and provides guidance in terms of leadership education development.

Keywords: business management; Generation Z; gender; gender-based leadership; leadership perceptions; leadership characteristics; survey; South Africa; undergraduate students.

\section{Introduction}

As South Africa is a multicultural country with an extremely diverse workforce, it is imperative that leaders in South Africa have the skills to effectively manage diversity to facilitate efficient follower commitment, as well as the opportunity for human capacity and organisational development (Getz \& Roy 2013:1; Rosenberg, Lotz-Sisitka \& Ramsarup 2018:250). Leadership in a developing nation such as South Africa is underdeveloped in comparison to First World nations due to insufficient academic provision for leadership development, as well as a lack of leadership training (El-Gohary \& Eid 2013:180). Leadership development is vital as it enriches leadership capabilities which are necessary for improved performance and involves influencing subordinates towards organisational goals (Dartey-Baah \& Addo 2019:148). El-Gohary and Eid (2013:180) further state that young leaders have the potential to facilitate change and innovation in business environments, thus improving economic growth and organisational efficiency. As South African students studying within the field of business management on undergraduate level are between the age of 18 and 22, these students could be seen as the business leaders 
of tomorrow. This age group also classifies these students as part of Generation Z, and thus their perceptions and preferences regarding leadership in the future have become critical factors to take into consideration when focusing on South Africa's future business leaders (Ramachandiran \& Dhanapal 2018:2117).

In terms of how leadership has a current impact on businesses in South Africa, the Global Entrepreneurship Monitor of 2017/2018 (2018) states that, amongst other reasons, smalland medium-sized businesses in South Africa are neither surviving nor growing because of a lack of leadership. Furthermore, the lack of academic provision of leadership development in terms of the youth of South Africa, especially in terms of Generation Z, is a significant problem, which creates a need for decision-makers throughout the country (Crowne 2019:2). These decision-makers will have to enhance the collaboration between higher education institutions and businesses to promote the development of leadership, as well as convey the important contribution which leadership makes towards future prosperity for individuals and businesses (Feagan 2018:681). It has, therefore, been suggested that there is a need to expand leadership development training, not only to South African businesses but also to universities that have been called upon to produce a new generation of sustainability leaders (Feagan 2018:682). This expansion could possibly create efficient future leaders and thus might reduce the high failure rate experienced by small, medium and micro businesses (Isa et al. 2018:149; Ladzani, Smith \& Pretorius 2012:3989).

As South Africa has a very diverse workforce, it is important to provide an understanding of the multi-dimensional concept of leadership and what it entails, through a literature review. Rahman (2016:207) noted that the study of leadership and leadership theories reveals a lack of consensus on the idea of leadership and divides experts, business organisations and government organisations. Leadership, in the traditional sense, is seen as being a hierarchy (i.e. top-down) management approach where decisions and actions are primarily made and discussed at top-level management and carried out through the lower levels (Denning 2015:14). A prominent finding when investigating leadership literature in a business or organisational context is that of the large number of leadership styles. However, for the aim of this study, the four predominant styles will be focused on and include (1) charismatic leadership, (2) servant leadership, (3) transactional leadership and (4) transformational leadership. Getz and Roy (2013:2) noted that, due to a variety of cultural norms, there is a lack of clarity as to which leadership style is prominent in South Africa. Along with these leadership styles, various traits and characteristics need to be taken into consideration, and even more so in terms of how South Africa's current youth (i.e. especially Generation Z), as potential future business leaders, would interpret such information (Abbasiyannejad et al. 2015:71; Bornman \& Puth 2017:6; Deverachetty 2012:63; Grow \& Yang 2018:9).
Taking this into account, it is also important to determine how the four dominant styles of leadership differ between genders based on their perceptions. Males are perceived to make use of a transactional leadership style, while females are perceived to utilise transformational leadership styles. However, it is perceived that males, rather than females, are more effective leaders (Grow \& Yang 2018:9; Kaiser \& Wallace 2016:73; Lai 2011:4).

\section{Purpose statement}

The main purpose of this study is to investigate the perceptions male and female undergraduate business management students at a tertiary institution in South Africa have towards leadership and gender-based leadership as these students are to be the potential future business leaders in South Africa and form part of Generation Z.

\section{Problem statement}

When assessing students' perceptions of leadership, previous research primarily focused on participative and collaborative leadership styles and failed to assess the dominant leadership styles in South African society, especially in terms of Generation Z and their preferences per gender (Chillakuri \& Mahanandia 2018:34; Crowne 2019:2).

The phenomenon of the leadership perceptions held by students, specifically in terms of gender-based perceptions, has largely been untouched in a South African context, and no evidence was found of such research in the context of economic and management science students at a South African tertiary institution. Therefore, this study aims to bridge the evident gap in the body of knowledge in this specific focus area and to provide insight into the perceptions and preferences of young male and female students (i.e. Generation $\mathrm{Z}$ students) as potential future leaders.

\section{Research objectives}

By taking the problem statement into account, the study's research objectives are to:

- Investigate the perceptions of undergraduate business management Generation Z students towards leadership.

- Investigate which style of leadership undergraduate business management Generation Z students prefer business leaders to exhibit.

- Test if male and female Generation Z students differ in their perceptions regarding the extent to which effective business leader exhibit transactional and transformational leadership styles.

- Test whether Generation Z students perceive it to be more important for a good business leader to exhibit stronger masculine traits as opposed to feminine traits.

- Test whether female Generation Z students perceive business leaders to exhibit a transformational leadership style compared to male students.

- Test whether male Generation Z students perceive business leaders to exhibit a transactional leadership style compared to female students. 
This study intends to contribute towards enhancing all business-related degrees offered by tertiary institutions in South Africa as it will enable, for example, universities to develop and implement correctly developed leadership courses within these degrees. By doing so, this will enable Generation Z students to not only improve their leadership knowledge, but also become more effective and successful business leaders. The results of this study can also contribute to further insight into how current business leaders are perceived and how future business leaders are expected to behave to be successful within their prospective working environments.

\section{Literature review}

Within the literature review, key terms and concepts were investigated, which include aspects such as defining leadership, focusing on different leadership styles, traits and characteristics (including charismatic, servant, transformational and transactional leadership), Generation Z and gender-based perceptions of leadership, before unpacking the study's hypotheses.

\section{Defining leadership}

Although the definition for leadership is seen as nonconcrete and various elements form part of how leadership is defined, for the basis of this study the definition compiled by Winston and Patterson (2006:7) will be utilised as it provides an integrative definition of leadership and incorporates what a leader is and the roles that a leader is involved in. The definition describes a leader as (Winston \& Patterson 2006):

$[O]$ ne or more people who selects, equips, trains, and influences one or more followers who have diverse gifts, abilities, and skills and focuses the followers to the organisation's mission and objectives causing the followers to willingly and enthusiastically expend spiritual, emotional, and physical energy in a concerted coordinated effort to achieve the organisational mission and objectives. (p. 7)

From this definition it can be note that leadership: (1) requires a leader who can motivate and inspire others to achieve organisational goals and (2) requires followers who have the necessary skills, abilities and willingness to successfully meet organisational goals and objectives in a coordinated manner. Dartey-Baah (2015:100) adds to this notion by stating that leadership is about initiation; it involves people (i.e. followers) and it focuses on providing direction to resources, behaviours and energies towards goal achievement. Therefore, through a leader-follower relationship, organisational missions and objectives are reached through the process of leadership. Bornman and Puth (2017:7) state that the process of leadership changes constantly, and individuals experience and perceive unique leadership moments recurrently; therefore, it is important to note that leadership is implemented in various ways based on a leader's characteristics or traits, as well as the leadership style chosen by the specific leader.

\section{Leadership styles, traits and characteristics}

Although previous studies have identified a large number of leadership styles; the predominant styles include (1) charismatic leadership, (2) servant leadership, (3) transactional leadership and (4) transformational leadership; the styles have been selected for the purpose of this study. Each leadership style is different and requires specific roles to be undertaken by the leaders (Gachter et al. 2012:953; Schyns et al. 2012:1). Although not forming part of this study, each of these leadership styles will also have to be adapted when taking into consideration how global developments such as the Fourth Industrial Revolution unfolds, and how culturally diverse business associates or teams will have to be able to effectively manage themselves while being spread out geographically (Ardito et al. 2019:323; Nascimento et al. 2019:607).

Furthermore, it is evident in previous studies that a leader's effectiveness and success are dependent on his or her personality traits. The trait theory mentions that leadership is solely dependent on a leader's characteristics or personal traits (Bolton, Brunnermeier \& Veldkamp 2013:515; Judge et al. 2002:765). However, Hughes, Ginnett and Curphy, and Yukl and Van Fleet (in Judge et al. 2002:765) argue that traits may differ according to the situation. It can, therefore, be concluded that each leader possesses a set of personal traits, using specific traits for certain styles of leadership.

\section{Charismatic leadership}

Charismatic leaders have the ability to confidently create a powerful, clear and compelling vision for the future, which creates excitement with and builds the commitment of the followers. This enables the leader to align his or her followers' vision with that of the leaders, encouraged by the leader's unconventional behaviour. The followers become extremely dependent on their leader, allowing them to be influenced to act in such a way that enables the leader to achieve his or her vision (Abbasiyannejad et al. 2015:70; Mittal 2015:27).

\section{Servant leadership}

Servant leadership focuses on building strong long-term relationships between a leader and a follower, where the leader develops a deep understanding of each follower's aspirations, skills and needs. These leaders place followers before themselves and are committed to help followers develop their full potential (James 2015:115).

\section{Transactional leadership}

Transactional leadership occurs through the use of rewards and punishments, thereby aligning follower performance to achieve specific actions (Afshari \& Gibson 2016:509; James 2015:114; Burns in Jogulu \& Wood 2008:602). Avolio, Bass and Jung (in Matsuo 2012:611) state that transactional leadership 
is based on three dimensions: (1) contingent reward (i.e. if the leader's expectations are met, the followers are rewarded and given praise for their achievements), (2) passive management by exception (i.e. when a leader intervenes once a mistake has been made or a problem has occurred) and (3) active management by exception (i.e. the leader constantly observing his or her followers, allowing for him or her to anticipate possible problems and to intervene immediately to prevent the problems from occurring) (Afshari \& Gibson 2016:509; Brown 2014:11; Lai 2011:3; Matsuo 2012:611; Tung 2016:1252).

\section{Transformational leadership}

As there are various definitions for leadership, transformational leadership is sometimes confused with transformative leadership (Montuori \& Donenelly 2017:4). Transformative leadership refers to leadership that focuses on everyone, everywhere and every day, whereas transformational leadership focuses on developing a commitment to a shared vision or goal for both leaders and followers, establishing high moral values within the organisation and recreating the organisation to ensure survival in a challenging market (Mary 2005:108; Tung 2016:1251). According to previous research (Dartey-Baah 2015:102; Grant 2012:459; Judge \& Piccolo 2004:755; Kroon, Van Woerkom \& Menting 2017:285; Lai 2011:3); there are four dimensions contained in transformational leadership. These include: (1) idealised influence (i.e. the leader's charismatic appeal and capability of being an ethical, moral and inspirational role model to the followers), (2) inspirational motivation (i.e. the leader's ability to encourage and motivate his or her followers in a positive and enthusiastic manner), (3) intellectual stimulation (i.e. the leader's ability to facilitate creativity and innovation through encouraging the followers to think differently and solve problems in new and creative ways) and (4) individual consideration (i.e. the leader's role in increasing his or her followers' potential).

As each leader utilises different leadership styles which attributed to their success, it is evident that each leader possesses a set of important characteristics that play an extremely critical role in the leadership process. There are a variety of leadership styles and leadership characteristics that can be implemented in the leadership process. However, one must note that there is a degree of ambiguity surrounding leadership; therefore, it is important to discuss the difference in perceptions that result in the selection of a specific leadership style.

\section{Generation Z}

According to Ramachandiran and Dhanapal (2018:2117), individuals born into the world of technology between 1995 and 2012 are classified as the cohort Generation Z. Generation $Z$ are children of millennials (i.e. Generation $Y$ ) and possess qualities such as being loyal, thoughtful, responsible and determined, while being less motivated by money and more entrepreneurial than millennials
(Chillakuri \& Mahanandia 2018:34). Bencsik, Horváth-Csikós and Jubász (2016:93) point out that these individuals are also known as 'the net generation', the 'iGeneration' or 'digital natives'. In some cases even referred to as 'screenagers', these individuals also have characteristics which include that they are independent in nature but can collaborate or connect well with others, can multitask, not afraid of continuous changes, are flexible in terms of their workplace, have experienced global exposure and are seen as technology proficient.

Furthermore, as Generation Z has been exposed to technology from an early age, this has had a major effect on higher education institutions and businesses' working environments. These sectors have had to go through a paradigm shift with the advancements of technology challenging the traditional system of learning, as well as the traditional workplace environment. Instead of Generation $\mathrm{Z}$ individuals asking where they see themselves in their respective organisations, these individuals are asking what a business or organisation could offer them in terms of growth opportunities or different experiences (Lidija et al. 2017:5).

\section{Gender-based perceptions of leadership}

For leaders to influence their followers, it is imperative that leaders create a perception that will have a strong influence on how their followers perceive them. Lindsay and Norman (in El-Gohary \& Eid 2013:183) define perceptions as 'the process by which organisms interpret and organise sensation to produce a meaningful experience of the world'. Along this notion, Getz and Roy (2013:2) conducted research investigating the perceptions of university students regarding which leadership style they prefer and found that university students favour the transformational leadership style. Investigating the viewpoints and opinions regarding leadership of undergraduate Generation Z students studying business management can therefore assist to determine their perceptions towards leadership (Shaked, Gross \& Glanz 2019:294).

Individuals are able to categorise a leader as effective or ineffective based on their perceptions towards leadership, and thus these perceptions play an instrumental role across numerous levels, namely: the societal, organisational, interpersonal and individual levels of how males and females perceive leadership (Lai 2011:1; Shaked et al. 2019:294). A form of perception that is most commonly formed when addressing leadership is the stereotyping of individuals into groups based on their gender, and this influence of stereotyping of males and females could enable an understanding as to why people find it difficult to accept females as leaders and see them as ineffective (Grow \& Yang 2018:9). In society, leadership is perceived to consist of masculine traits such as ambition, assertiveness, control, persuasion, aggression and distancing one's personal self from their role as a leader. These traits are perceived to be 
needed for success and are strongly associated with men rather than with women (Lai 2011:5; Shaked et al. 2019:294).

In contrast, society perceives females as having communal qualities, such as warmth, selflessness, nurturing nature, compassion, participative qualities and an emphasis on people skills which are not perceived as qualities for effective leadership (Eagly \& Carli 2003:818; Grow \& Yang 2018:9; Kaiser \& Wallace 2016:73). This gives rise to the phenomenon of role incongruity for female leaders, as they are less likely to fit the conventional model of leadership and are discriminated against due to the perception that they do not exhibit more traditional masculine traits (Eagly \& Carli 2003:818; Lai 2011:6; Scheepers, Douman \& Moodley 2018:467).

\section{Hypotheses}

As transactional leadership is seen as a very effective and important leadership style, it guarantees that the objectives of leaders are met. On the other hand, transformational leadership can be seen as even more important as the objectives of the leader are met above and beyond expectations and done by building a strong base of employee motivation (Afshari \& Gibson 2016:509; Breevaart et al. 2014:139). Thus, the first hypothesis that was formulated states:

$\mathbf{H}_{\mathbf{1}}$ : Generation $\mathrm{Z}$ students perceive it to be more important for a good business leader to exhibit stronger masculine traits as opposed to feminine traits.

However, it has been noted that females in a position of leadership exhibit transformational leadership behaviour as it exemplifies perceived feminine types of behaviour and females have a tendency to exhibit more emotional intelligence than males (Jogulu \& Wood 2008:604; LopezZafra, Garcia-Retamero \& Martos 2012:98-99; Shaked et al. 2019:294). Eagly et al. (in Eagly \& Carli 2003:817) state that females also engage in a dimension of transactional leadership behaviour, namely contingent reward. Therefore, transformational leadership, along with the dimension of contingent reward, is more associated with female leaders, thus leading to the suggestion proposed by the author that there is an existence of female advantage (Lai 2011:5).

Male leaders, however, are associated with transactional leadership and are more likely to exhibit active or passive management by exception, as this dimension is congruent with masculine behaviour (Eagly \& Carli 2003:817; Grow \& Yang 2018:9). The following two hypotheses are thus stated:

\footnotetext{
$\mathbf{H}_{2}$ : Female Generation $\mathrm{Z}$ students perceive business leaders to exhibit transformational leadership style characteristics compared to the perceptions of male students.
}

$\mathbf{H}_{3}$ : Male Generation $\mathrm{Z}$ students perceive business leaders to exhibit stronger transactional leadership style characteristics compared to the perceptions of female students.

Followers only react positively to contingent reward and negatively to the other transactional leadership dimension, management by exception (Grow \& Yang 2018:9; Jogulu \& Wood 2008:603). Therefore, from previous studies, it was found that transformational leadership is associated with a more effective leadership style than transactional leadership.

\section{Methodology}

Now that the hypotheses have been formulated, the methodology section focuses on the sampling method, sample design, research design, the target population and units of analysis that was employed in this study.

\section{Sampling method and sampling design}

This study used a non-probability sampling method (i.e. convenience sampling) as a specific population element of the sample was not known nor could it be determined prior to the collection of data. This was due to the fact that the researcher was not able to predict the number of registered students who would partake when the questionnaires were distributed (Cooper \& Schindler 2014:343). After ethical clearance was obtained from the selected tertiary institution, the questionnaires were distributed in various undergraduate business management classes after the lectures ended. Utilising a convenience sampling method could, however, lead to a sample selection bias as the selection of sample elements is left entirely to the discretion of the field workers. Furthermore, sample selection may have occurred due to the self-selection by the students to participate in the study (University of Pretoria 2018:14). Thus, the sample may not be representative of the entire population group.

As the selected sample was undergraduate students between the age of 18 and 22, these students form part of Generation $Z$ and are different to previous generations such as Generation Y (Chillakuri \& Mahanandia 2018:34). This also points out that current Generation $\mathrm{Z}$ students will have different perceptions and preferences than previous generations and makes the study critical in terms of how potential future business leaders in South Africa perceive business leadership.

The aim of this study was to achieve a minimum sample size of 200 respondents. This study's questionnaire was handed out to 469 students, and the final realised sample included a total of 320 students responded by completing the questionnaire. This resulted in a $68 \%$ response rate. All 320 questionnaires were usable and analysed.

\section{Research design}

Formulating the research design, firstly a synthesis of different questionnaires was utilised, and different scales were adopted to formulate a completely new questionnaire.

In terms of the perceptions of transactional and transformational leadership, the Multi-factor Leadership Questionnaire (MLQ) developed by Bass and Avolio (in Xiaoxia \& Jing 2006:53) was adopted. This scale consists of an 18-item, 7-point Likert scale. The MLQ was also used by Xiaoxia and Jing (2006:1-114) and makes use of a 7-point rating scale labelled from 0 (totally disagree) to 6 (totally agree). In this study, however, the scale was adapted to a 
5-point Likert scale, labelled from 1 (strongly disagree) to 5 (strongly agree). The wording throughout the scale was changed to measure students' perceptions of a business leader rather than the perception of themselves as leaders, and the questions on risk acceptance and laissez-faire leadership were excluded as they do not apply to this study. The scale measures two sub-dimensions, namely, transactional leadership and transformational leadership. For each subdimension, a composite score was calculated. This was achieved by averaging the respondents' answers across each individual item in the sub-dimensions. The higher the composite score on a certain sub-dimension, the more the respondent favoured that specific leadership style. A reliability analysis of the scale provided a Cronbach's Alpha coefficient of 0.75 signifying satisfactory reliability and internal consistency of the data (Van Jaarsveld, Mentz \& Ellis 2019:604).

In terms of masculine and feminine traits, Sczesny et al.' (2004:636) scale was used to measure students' perceptions regarding the importance of masculine and feminine traits exhibited by good business leaders. The scale used by Sczesny et al. (2004:636) is a 7-point rating scale ranging from 0 (not at all important) to 6 (extremely important). However, this scale was adapted in the study and is labelled from 1 (unimportant) to 7 (very important). Furthermore, the characteristics and traits used in this scale have been adjusted to include those that have been discussed in the literature review, as well as those used by Sczesny et al. (2004:636) which apply to the study. This 10-item, 7-point multiple rating scale measures two sub-dimensions namely masculine traits and feminine traits. For each sub-dimension a composite score was calculated. This was achieved by averaging the respondents' answers across each individual item in the subdimensions. The higher the composite score on a certain subdimension, the more a respondent perceived it to be important. A reliability analysis of the scale provided a Cronbach's Alpha value of 0.54 . No comparison could be made to the study by Sczesny et al. (2004:631-645) as these authors used percentage estimates to measure the reliability of the scales.

\section{Target population and units of analysis}

As Generation $\mathrm{Z}$ will present new challenges to leaders, managers and educators in every sector of the workforce, it is imperative to investigate this generation as the study's target population (Lidija et al. 2017:5). The target population of this study therefore consisted of undergraduate male and female Generation Z students who were studying business management at a tertiary institution in South Africa. As these students were born between 1995 and 2012, it establishes them as Generation $\mathrm{Z}$ students, and within the demographic questions it was asked what age each respondent was. If a respondent did not fall within the age bracket of Generation $\mathrm{Z}$, then the questionnaire was discarded. The units of analysis are the individual undergraduate business management student as the purpose of this study is to measure the perceptions towards leadership of undergraduate students studying business management. Other researchers in the field of leadership have included students in their samples (Crowne 2019:82; El-Gohary \& Eid 2013:185; Getz \& Roy 2013:3; Gird \& Bagraim 2008:714; Ramachandiran \& Dhanapal 2018:2117.) and for this reason the study included students as the target population.

Getz and Roy (2013:3), suggest that an individual's personality traits between the ages of 18 and 22 have the greatest potential to be influenced. Furthermore, these individuals become more independent during their years at university, which becomes the period in which they adopt a preferred leadership style. Given these reasons, the study requires that students who partake in the study be between the ages of 18 and 22, which also classified these students as being part of Generation Z.

\section{Data collection}

After an initial pre-test of the questionnaire was completed with a convenience sample of 10 undergraduate students at a tertiary institution in South Africa, the data for the main study were collected by means of a self-completion questionnaire. The questionnaires were administered and distributed in the last 10-15 min of undergraduate business management lectures at a tertiary institution in South Africa. No incentives were given to the students to complete the survey, and this was the most appropriate method due to the cost effectiveness and time constraints (Cooper \& Schindler 2014:228). Furthermore, this method has been used in previous research studies by various authors and researchers (Getz \& Roy 2013:1-10; Gird \& Bagraim 2008:711-724; McDowell, Huang \& Caza 2018:227; Munyaka et al. 2017:1; Ramachandiran \& Dhanapal 2018:2117).

\section{Results}

\section{Comparative descriptive statistics}

Table 1 contains the composite means and standard deviations of the constructs measured in the study. On average, male Generation Z students scored higher on both the transformational leadership style and the transactional leadership style. Transformational leadership traits and servant leadership traits are preferred by students, and feminine traits are perceived as more important than masculine traits by both gender groups.

The demographic profile of respondents indicated that the majority of the respondents were female (55.3\%). Most of the respondents were between the ages of 18 and 19 (57.2\%).

\section{Hypotheses tests}

Each hypothesis tested in this study is a one-tailed (directional) hypothesis, tested at a $5 \%$ level of significance (i.e. $\alpha=0.05$ ).

The first hypothesis $\left(\mathrm{H}_{1}\right)$ focused on Generation $\mathrm{Z}$ students' perceptions of the importance of masculine and feminine 
TABLE 1: Construct's composite mean scores and standard deviations.

\begin{tabular}{|c|c|c|c|c|c|c|}
\hline \multirow[t]{3}{*}{ Construct } & \multicolumn{4}{|c|}{ Gender } & \multirow{2}{*}{\multicolumn{2}{|c|}{ Total }} \\
\hline & \multicolumn{2}{|c|}{ Male } & \multicolumn{2}{|c|}{ Female } & & \\
\hline & $M$ & SD & $M$ & SD & $M$ & SD \\
\hline Total: Transformational leadership style & 4.10 & 0.38 & 4.09 & 0.39 & 4.09 & 0.39 \\
\hline Total: Transactional leadership style & 4.01 & 0.39 & 4.00 & 0.41 & 4.01 & 0.40 \\
\hline Total: Charismatic leadership traits & 1.90 & 0.56 & 1.72 & 0.54 & 1.80 & 0.56 \\
\hline Total: Transformational leadership traits & 4.37 & 0.34 & 4.39 & 0.34 & 4.38 & 0.34 \\
\hline Total: Transactional leadership traits & 2.92 & 0.63 & 2.71 & 0.60 & 2.80 & 0.62 \\
\hline Total: Servant leadership traits & 4.09 & 0.44 & 4.06 & 0.35 & 4.07 & 0.39 \\
\hline Total: Masculine traits & 5.10 & 0.75 & 5.01 & 0.71 & 5.05 & 0.73 \\
\hline Total: Feminine traits & 5.63 & 0.70 & 5.72 & 0.59 & 5.68 & 0.64 \\
\hline
\end{tabular}

$\mathrm{M}$, mean; SD, standard deviation.

traits of a good business leader. The null and alternative hypotheses of $\mathrm{H}_{1}$ are stated below:

$\mathrm{H}_{1 \text { (null) }}$ : Generation $\mathrm{Z}$ students do not perceive it to be more important for a good business leader to exhibit stronger masculine traits as opposed to feminine traits.

$\mathbf{H}_{1 \text { (alt) }}$ : Generation $\mathrm{Z}$ students' perceive it to be more important for a good business leader to exhibit stronger masculine traits as opposed to feminine traits.

As the respondents' perceptions of the importance of the masculine and feminine traits were measured at an interval level of measurement, the appropriate parametric significance test is the paired samples $t$-test. If the assumptions are violated, the non-parametric Wilcoxon's signed rank test can be used (Pallant 2016:204). The paired samples $t$-test assumes that the difference between the two scores of each pair of variables has a normal distribution. In large samples, minor violations of this assumption should not cause problems (Pallant 2016:245). The Kolmogorov-Smirnov test for normality and histograms and normal probability plots were used to test for the assumption of normality (Pallant 2016:63). These tests suggest slight departures from normality for both difference scores. As the data violated the assumptions of normality of the paired samples $t$-test, the nonparametric Wilcoxon's signed rank test was used to test $\mathrm{H}_{1}$. The descriptive statistics and the results of Wilcoxon's signed rank test are presented in Table 2 .

The descriptive statistics in Table 2 suggest a sizeable difference $(5.68-5.05=0.63)$ in the mean scores of masculine traits $(\mathrm{M}=5.05, \mathrm{SD}=0.72)$ and feminine traits $(\mathrm{M}=5.68$, $\mathrm{SD}=0.64)$. As, on an average, respondents regarded feminine traits as more important than masculine traits, these descriptive statistics suggest that, contrary to the expectations of formulated hypothesis $\mathrm{H}_{1}$. Generation $\mathrm{Z}$ students perceive it to be important for good business leaders to exhibit stronger feminine traits. The two-tailed $p$-value is statistically significant as it is 0.00 ; however, the difference in mean scores is at odds with what was hypothesised. The two-tailed $p$-value was, therefore, adjusted to a one-tailed $p$-value of 0.99 , using the formula 1 - (two-tailed $p$-value $/ 2$ ) which was calculated as follows: $1-(0.001 / 2)$. As the difference in the means is in the opposite direction to what was expected, $\mathrm{H}_{1 \text { (alt) }}$ cannot be accepted.
TABLE 2: Descriptive statistics and results of Wilcoxon's signed rank test conducted on $\mathrm{H}_{1}$.

\begin{tabular}{|c|c|c|c|c|c|}
\hline Hypothesis & Variables & $n$ & $\mathbf{M}$ & SD & $\begin{array}{l}\text { Results: Wilcoxon's signed } \\
\text { rank test }\end{array}$ \\
\hline \multirow[t]{2}{*}{$\mathrm{H}_{1}$} & Masculine traits & 320 & 5.05 & 0.72 & \multirow[b]{2}{*}{$\begin{array}{l}\text { Test statistic: } \\
-11.07 \\
\text { Two-tailed } p \text {-value: } 0.00 \\
\text { One-tailed } p \text {-value: } \\
0.99 \\
\text { Conclusion: } \\
\text { No significant difference; } \mathrm{H}_{1(\text { null) }} \\
\text { cannot be rejected. }\end{array}$} \\
\hline & Feminine traits & 320 & 5.68 & 0.64 & \\
\hline
\end{tabular}

The second hypothesis $\left(\mathrm{H}_{2}\right)$ focused on how the genders differed in their perceptions regarding transformational leadership. The null and alternative hypotheses of $\mathrm{H}_{2}$ are stated below:

$\mathbf{H}_{2 \text { (null) }}$ : Generation $\mathrm{Z}$ male and female students do not differ in their perceptions of the extent to which business leaders exhibit transformational leadership style characteristics.

$\mathbf{H}_{2 \text { (alt): }}$ Generation $\mathrm{Z}$ female students perceive business leaders to exhibit transformational leadership style characteristics compared to the perceptions of male students.

As respondents' perceptions of the extent to which business leaders exhibit transformational leadership characteristics was measured at an interval level of measurement, the appropriate parametric significance test is the independent samples $t$-test. If the assumptions are violated, the nonparametric Mann-Whitney $U$ test can be used (Pallant 2016:227). The independent samples $t$-test assumes that the variable on which the two groups are being compared must have a normal distribution in both groups (Pallant 2016:206). In large samples, minor violations of this assumption should not cause problems (Pallant 2016:206). Furthermore, it assumes that the variance of the scores for the two groups is equal (Pallant 2016:241). The Kolmogorov-Smirnov test for normality and histograms and normal probability plots were used to test for the assumption of normality (Pallant 2016:63). These tests suggest a significant departure from normality in the male sub-group. Since the data violated the assumption of normality for the independent samples $t$-test in the male sub-group, the non-parametric Mann-Whitney $U$ test was used to test $\mathrm{H}_{2}$. The descriptive statistics and the results of the Mann-Whitney $U$ test are presented in Table 3.

The descriptive statistics in Table 3 suggest a small difference $(4.10-4.09=0.01)$ in the mean transformational leadership style scores of the male $(\mathrm{M}=4.10, \mathrm{SD}=0.38)$ and female 
TABLE 3: Descriptive statistics and results of Mann-Whitney $U$ test conducted on $\mathrm{H}_{1}$.

\begin{tabular}{|c|c|c|c|c|c|c|}
\hline Hypothesis & Sub-dimension & Gender & $N$ & $\mathbf{M}$ & SD & $\begin{array}{l}\text { Results: Mann-Whitney } \\
U \text { test }\end{array}$ \\
\hline \multirow[t]{2}{*}{$\mathrm{H}_{2}$} & \multirow{2}{*}{$\begin{array}{l}\text { Total: } \\
\text { Transformational } \\
\text { leadership style }\end{array}$} & & 143 & 4.10 & 0.38 & \multirow{2}{*}{$\begin{array}{l}\text { Test statistic: } \\
-0.30 \\
\text { One-tailed } p \text {-value: } \\
0.62 \\
\text { Conclusion: } \\
\text { No significant difference; } \\
\mathrm{H}_{2 \text { (null) }} \text { cannot be rejected. }\end{array}$} \\
\hline & & Female & 177 & 4.09 & 0.39 & \\
\hline
\end{tabular}

$\mathrm{M}$, mean; SD, standard deviation.

sub-groups $(\mathrm{M}=4.09, \mathrm{SD}=0.39)$. A higher mean score on the transformational leadership style sub-dimension indicates a stronger perception of business leaders exhibiting transformational leadership characteristics. These descriptive statistics, therefore, suggest that, contrary to the expectation of $\mathrm{H}_{2}$, male Generation $\mathrm{Z}$ students perceive business leaders to exhibit transformational leadership style characteristics a slight bit more than Generation $\mathrm{Z}$ female students. The observed difference in the average transformational leadership scores for male and female Generation Z students is not statistically significant, indicated by the one-tailed $p$-value of $0.62(1-(0.764 / 2))$ in the last column, which is greater than 0.05 . Therefore, $\mathrm{H}_{2 \text { (alt) }}$ cannot be accepted.

The third hypothesis $\left(\mathrm{H}_{3}\right)$ focused on the how the genders differed on their perceptions regarding transactional leadership. The null and alternative hypotheses of $\mathrm{H}_{3}$ are stated below:

$\mathbf{H}_{3 \text { (null) }}$ : Generation $\mathrm{Z}$ male and female students do not differ in their perceptions of the extent to which business leaders exhibit transactional leadership style characteristics.

$\mathbf{H}_{3 \text { (alt) }}$ : Generation $\mathrm{Z}$ male students perceive business leaders to exhibit stronger transactional leadership style characteristics compared to the perceptions of female students.

As respondents' perceptions of the extent to which business leaders exhibit transactional leadership characteristics was measured at an interval level of measurement, the appropriate parametric significance test is the independent samples $t$-test. If the assumptions are violated, the nonparametric Mann-Whitney $U$ test can be used (Pallant 2016:227). The independent samples $t$-test assumes that the variable on which the two groups are being compared must have a normal distribution in both groups (Pallant 2016:206). In large samples, minor violations of this assumption should not cause problems (Pallant 2016:206). Furthermore, it assumes that the variance of the scores for the two groups is equal. The Kolmogorov-Smirnov test for normality and histograms and normal probability plots were used to test for the assumption of normality (Pallant 2016:63). These tests indicate significant departures from normality in both sub-groups. As the data violated the normality assumption of the independent samples $t$-test, the non-parametric Mann-Whitney $U$ test was used to test $\mathrm{H}_{3}$. The descriptive statistics and results are presented in Table 4.

The descriptive statistics in Table 4 suggest a small difference $(4.01-4.00=0.01)$ in the mean scores of transactional leadership between the male $(\mathrm{M}=4.01, \mathrm{SD}=0.386)$ and
TABLE 4: Descriptive statistics and results of the Mann-Whitney $U$ test conducted on $\mathrm{H}$.

\begin{tabular}{|c|c|c|c|c|c|c|}
\hline Hypothesis & Sub-dimension & Gender & $n$ & $\mathbf{M}$ & SD & $\begin{array}{l}\text { Results: Mann-Whitney } \\
U \text { test }\end{array}$ \\
\hline \multirow[t]{2}{*}{$\mathrm{H}_{3}$} & \multirow{2}{*}{$\begin{array}{l}\text { Total: } \\
\text { Transactional } \\
\text { leadership style }\end{array}$} & & 143 & 4.01 & 0.39 & \multirow{2}{*}{$\begin{array}{l}\text { Test statistic: } \\
-0.02 \\
\text { One-tailed } p \text {-value: } \\
0.51 \\
\text { Conclusion: } \\
\text { It is not significantly } \\
\text { different; } \mathrm{H}_{3 \text { (null) }} \text { not } \\
\text { rejected. }\end{array}$} \\
\hline & & Female & 177 & 4.00 & 0.41 & \\
\hline
\end{tabular}

$\mathrm{M}$, mean; SD, standard deviation.

female $(\mathrm{M}=4.00, \mathrm{SD}=0.408)$ Generation $\mathrm{Z}$ sub-groups. A higher mean score on the transactional leadership style sub-dimension indicates a stronger perception of business leaders exhibiting transactional leadership characteristics. These descriptive statistics, therefore, suggest that, similar to the expectations of $\mathrm{H}_{3}$, Generation $\mathrm{Z}$ male and female students do not differ in their perceptions of the extent to which business leaders exhibit transactional leadership style characteristics. The one-tailed $p$-value of $0.51(1-(0.982 / 2))$ in the last column of the Table 4 is greater than 0.05 ; therefore, $\mathrm{H}_{3 \text { (alt) }}$ cannot be accepted.

\section{Discussion}

The results of $\mathrm{H}_{1}$ show that both male and female Generation $\mathrm{Z}$ students perceive it to be more important for business leaders to exhibit feminine traits. This is contradictory to the results found by Eagly and Carli (2003:818-819), Grossman, Komai and Jensen (2015:368-388), Javidan, Bullough and Dibble (2016:59-73), Lai (2011:5), which state that masculine traits such as ambition, assertiveness, control, persuasion, aggression and the act of distancing one's personal self from their leadership role, are perceived to be more important for success. The study found that male Generation Z students perceived feminine traits to be more important than masculine traits. This could be attributed to the increase in preference for the transformational leadership style, which embodies feminine traits (Grossman et al. 2015:368-388; Jogulu \& Wood 2008:604; Lopez-Zafra et al. 2012:98-99). This increase in preference for the transformational leadership style was made evident when testing $\mathrm{H}_{2}$ and $\mathrm{H}_{3}$. The study found that the total sample perceived effective business leaders to exhibit stronger transformational leadership style characteristics than transactional leadership style characteristics.

The findings for $\mathrm{H}_{2}$, which measure Generation $\mathrm{Z}$ females' perceptions relating to the transformational leadership style, are not consistent with previous studies. The previous studies found that female leaders are strongly associated with the transformational leadership style as it is congruent with feminine traits (Javidan et al. 2016:59-73; Jogulu \& Wood 2008:604; Lai 2011:5; Lopez-Zafra et al. 2012:98-99). However, the study found that male Generation $Z$ students perceive effective business leaders to exhibit a transformational leadership style slightly more than female Generation Z students. The small mean difference of 0.01 that was found, however, is not statistically significant and therefore does not indicate a real difference between the male and female 
Generation $\mathrm{Z}$ students from which the sample was drawn. Therefore, the findings from $\mathrm{H}_{2}$ determine that male and female Generation $\mathrm{Z}$ students do not differ in their perceptions of the extent to which business leaders exhibit transformational leadership style characteristics.

The same mean difference of 0.01 between male and female Generation Z students' perceptions was found when testing $\mathrm{H}_{3}$. This indicates that male Generation $\mathrm{Z}$ students showed a slightly stronger perception for the transactional leadership style than female Generation $\mathrm{Z}$ students. However, the mean value is not statistically significant and therefore does not indicate a real difference between the male and female Generation Z students from which the sample was drawn. These findings therefore determine that, similar to the transformational leadership style, male and female Generation $\mathrm{Z}$ students do not differ in their perceptions of the extent to which business leaders exhibit transactional leadership style characteristics. These findings are contradictory to previous studies which found that male leaders are strongly associated with transactional leadership as this leadership style is congruent with masculine behaviour (Javidan et al. 2016:59-73; Grossman et al. 2015:368-388; Eagly \& Carli 2003:817).

\section{Managerial implications}

In terms of tertiary institutions in South Africa, other higher education institutions and businesses, the results of this study provide guidance for the development of leadership, as well as convey the importance of leadership towards future prosperity for our country as a whole. Male and female Generation Z students did not differ significantly on any of the constructs. Transformational leadership was found to be favoured over transactional leadership by a slight margin by both gender groups, and feminine traits were found to be favoured over masculine traits. Therefore, given that transformational leadership has been most frequently cited in literature as the prominent and successful leadership style of the 21st century and that it exemplifies feminine traits, all leadership courses and training workshops should be aimed at encouraging future leaders to develop a transformational leadership style.

Therefore, tertiary institutions in South Africa and other higher education institutions should develop and implement leadership courses throughout all business-related degrees in order to enhance the students' leadership skills and aid them in their progression towards transformational leadership. Tertiary education institutions should therefore also expose students to more leadership development in a business context by conducting workshops with business leaders in different industries in order to broaden the students' perceptions of leadership.

\section{Limitations of the study}

The majority of the limitations of this study relate to data collection and interpretation. Firstly, this study was conducted on the main campus of one tertiary education institution using a nonprobability sampling method. This means that the probability of any element of the target population being chosen is unknown and cannot be calculated (Cooper \& Schindler 2014:343). Therefore, it cannot be established as to what degree the sample represents the target population. Thus, the results of this study cannot be generalised to other undergraduate Generation Z students studying business management at other tertiary education institutions in South Africa. Secondly, as the study focused solely on undergraduate students, the results of the study cannot necessarily be generalised to another context such as postgraduate students. Thirdly, there is a limitation regarding the MLQ measurement instrument which was used to measure transformational and transactional leadership. The reliability of this scale could not be compared to the study that the scale was adapted from, as the study did not use a Cronbach's Alpha to test the reliability of the scale. The MLQ measurement instrument has, however, been used in numerous studies (Bass et al. 2013:207-218; Goswami et al. 2016:1083-1099; Van Jaarsveld et al. 2019:604-613).

Furthermore, there is a limitation regarding the measurement instrument used to measure the characteristics and traits of a good business leader. The reliability of this scale could not be assessed. Thus, the characteristics and traits scale was assumed to have reliability. However, the Cronbach's Alpha value for this scale was below the recommended value of 0.7 which could not be improved by deleting items from the scale. Therefore, this is a limitation on this study. Furthermore, the reliability of the scale used to measure masculine and feminine traits of a good business leader could not be compared to the study that the scale was adapted from as the study used percentages to test for reliability.

\section{Recommendations for future research}

As the study's questionnaire was based on specific research objectives focusing on only certain leadership styles (i.e. the preference of transactional- and transformational leadership), it is recommended that for future studies it should be tested as the following: Generation $\mathrm{Z}$ students differ in their perceptions regarding the extent to which effective business leaders exhibit charismatic-, servant-, transactionaland transformational leadership styles. Furthermore, future research should expand the study's target population to postgraduate students to increase the accuracy of the results in relation to the population. It is also recommended that future studies survey business leaders along with students in order to obtain a comparison between these two groups. This will allow researchers to further determine if students understand leadership in a business context. Moreover, if this study proves to be successful, it can be conducted on a national scale to improve its accuracy and it could further incorporate an additional variable such as culture, as South Africa is a culturally diverse nation. 


\section{Conclusion}

As the importance of gender equality and the fair distribution of opportunities in the context of organisations are increasing, correct leadership styles and traits are becoming a critical aspect to organisational success. As undergraduate business management students at tertiary academic institutions are the next generation of possible business leaders; current leadership education and training should be aimed at developing potential future leaders who practice the correct leadership styles while implementing the correct leadership traits.

As leadership styles such as the transformational leadership style is perceived as preferred amongst undergraduate Generation Z students and as these future business leaders are constantly developing and transforming within their current educational environment, tertiary institutions need to implement the correct leadership training and make sure that these students get exposed to not just correct theories and literature but also to industry and practice. This type of leadership development, along with the inclusion of feminine traits (such as warmth, selflessness, a nurturing nature, compassion, participative qualities and an emphasis on people skills), could possibly create a stronger base for individuals who could become successful business leaders in future; it will help gather understanding about how they should conduct themselves within a competitive business work environment to ensure organisational success.

This study can contribute to the success that leadership education can have on understanding how leaders should act or behave, as well as effective leadership training and development. This study will also help to understand the interdependence of leadership development and genderbased traits which in general, as well as from a South African perspective, has to be further investigated as there is a lack of literature within this field.

If the correct and relevant leadership training and development is correctly implemented at earlier levels of education (i.e. during undergraduate studies), then potential future leaders might also later be able to develop their own followers and inspire or motivate them to develop as leaders themselves. This will in turn possibly craft a conducive leadership development environment in which transformational leadership and gender-based leadership traits can be integrated successfully to lead to organisational effectiveness, efficiency and success.

\section{Acknowledgements}

The author would like to acknowledge reviewers of the draft manuscript and would like to thank Mr D.I. Johnston and Ms B.C. Kettley for their helpful assistance during the development, data collection and analyses of the draft version of this manuscript.

\section{Competing interests}

The author declares that he has no financial or personal relationships which may have inappropriately influenced him in writing this article.

\section{Authors' contributions}

D.A.J.B. was the project leader and was also responsible for conceptualising the study, the study's methodology formulation and the writing of this manuscript.

\section{Ethical consideration}

Ethical clearance for this manuscript was obtained from the Department of Business Management as part of the Faculty of Economic and Management Sciences at the University of Pretoria.

\section{Funding}

This research received no specific grant from any funding agency in the public, commercial or not-for-profit sectors.

\section{Data availability statement}

Data sharing is not applicable to this article as no new data were created or analysed in this study.

\section{Disclaimer}

The views and opinions expressed in this article are those of the author and do not necessarily reflect the official policy or position of any affiliated agency of the author.

\section{References}

Abbasiyannejad, M., Siljong, A.D., Ismail, I.A., Othman, J. \& Wahat, N.W.A., 2015 'Charismatic leadership and society', International Research Journal of Social Sciences 4(1), 68-73.

Afshari, L. \& Gibson, P., 2016, 'How to increase organizational commitment through transactional leadership', Leadership \& Organization Development Journal 37(4), 507-519. https://doi.org/10.1108/LODJ-08-2014-0148

Ardito, L., Petruzzelli, A.M., Panniello, U. \& Garavelli, A.C., 2019, 'Towards industry 4.0: Mapping digital technologies for supply chain management-marketing integration' Business Process Management Journal 25(2), 323-346. https://doi.org/10.1108/ BPMJ-04-2017-0088

Bass, B.M., Avolio, B.J., Jung, D.I. \& Berson, Y., 2013, 'Predicting unit performance by assessing transformation and transactional leadership', Journal of Applied Psychology 88(1), 207-218. https://doi.org/10.1037/0021-9010.88.2.207

Bencsik, A., Horváth-Csikós, G. \& Jubász, T., 2016, 'Y and Z generations at workplaces', Journal of Competitiveness 8(3), 90-106. https://doi.org/10.7441/joc.2016. 03.06

Bolton, P., Brunnermeier, M.K. \& Veldkamp, L., 2013, 'Leadership, coordination, and corporate culture', Review of Economic Studies 80(1), 512-537. https://doi.org/ 10.1093/restud/rds041

Bornman, D.A.J. \& Puth, G., 2017, 'Investigating employee perceptions of leadership communication: A South African study', Journal of Contemporary Management 14(1), 1-23.

Breevaart, K., Bakker, A., Hetland, J., Demerouti, E., Olsen, O.K. \& Espevik, R., 2014, 'Daily transactional and transformational leadership and daily employee engagement', Journal of Occupational and Organizational Psychology 87(1), 138-157. https://doi.org/10.1111/joop.12041

Brown, C., 2014, 'The effects of emotional intelligence and leadership styles on sales performance', Economic Insights - Trends and Challenges 3(1), 1-14.

Chillakuri, B. \& Mahanandia, R., 2018, 'Generation Z entering the workforce: The need for sustainable strategies in maximizing their talent', Human Resources Management International Digest 26(4), 34-38. https://doi.org/10.1108/ HRMID-01-2018-0006

Cooper, D.R. \& Schindler, P.S., 2014, Business research methods, 12th edn., 228-343, McGraw-Hill/Irwin, New York. 
Crowne, K.A., 2019, 'Investigating antecedents of transformational leadership in students', Journal of International Education in Business 12(1), 80-94.

Dartey-Baah, K., 2015, 'Resilient leadership: A transformational-transactional leadership mix', Journal of Global Responsibility 6(1), 99-112. https://doi.org/ 10.1108/JGR-07-2014-0026

Dartey-Baah, K. \& Addo, S.A. 2019, 'Leaders as organisational representatives: A structural model', African Journal of Economic and Management Studies 10(2), 148-168. https://doi.org/10.1108/AJEMS-11-2017-0288

Denning, S., 2015, 'New lessons for leaders about continuous innovation', Strategy \& Leadership 43(1), 11-15. https://doi.org/10.1108/SL-11-2014-0083

Deverachetty, S., 2012, 'Women as charismatic leaders', Unpublished doctoral thesis, The University of Akron, Ohio, viewed 10 April 2018, from https://etd.ohiolink. edu/!etd.send_file\%3Faccession\%3Dakron1342500744\%26disposition\%3Dinline.

Eagly, A.H. \& Carli, L.L., 2003, 'The female leadership advantage: An evaluation of evidence', The Leadership Quarterly 14(6), 807-834. https://doi.org/10.1016/j. leaqua.2003.09.004

El-Gohary, H. \& Eid, R., 2013, 'Leadership teaching impact on tourism students' attitudes and perceptions toward leadership in developing economies: The case of Egypt', Journal of Hospitality \& Education 25(4), 180-192. https://doi.org/ 10.1080/10963758.2013.850297

Feagan, M.L., 2018, 'Fostering the next generation of sustainability leadership: Graduate student experiences with ecohealth communities of practice,
International Journal of Sustainability in Higher Education 19(4), 681-698. https:// doi.org/10.1108/IJSHE-11-2016-0202

Gachter, S., Nosenzo, D., Renner, E. \& Sefton, M., 2012, 'Who makes a good leader? Cooperativeness, optimism, and leading by example', Economic Inquiry 50(4), 953-967. https://doi.org/10.1111/j.1465-7295.2010.00295.x

Getz, M. \& Roy, M., 2013, 'Student leadership perceptions in South Africa and the United States', International Journal of Psychological Studies 5(2), 1-10. https:// doi.org/10.5539/ijps.v5n2p1

Gird, A. \& Bagraim, J.J., 2008, 'The theory of planned behaviour as predictor of entrepreneurial intent amongst final-year university students', South African Journal of Psychology 38(4), 711-724. https://doi.org/10.1177/008124630803800410

Global Entrepreneurship Monitor., 2018, Global report 2017 / 2018, viewed 03 September 2018, from https://www.gemconsortium.org/report.

Grant, A.M., 2012, 'Leading with meaning: Beneficiary contact, prosocial impact, and the performance effects of transformational leadership', Academy Management Journal 55(2), 458-476. https://doi.org/10.5465/amj.2010.0588

Goswami, A., Nair, P., Beehr, T. \& Grossenbacher, M., 2016, 'The relationship of leaders' humor and employee's work engagement mediated by positive emotions: Moderating effect of leaders' transformational leadership style', Leadership \& Organizational Development Journal 37(8), 1083-1099. https://doi.org/10.1108/ LODJ-01-2015-0001

Grossman, P.J., Komai, M. \& Jensen, J.E., 2015, 'Leadership and gender in groups: An experiment', Canadian Journal of Economics 48(1), 368-388. https://doi.org/ 10.1111/caje.12123

Grow, J.M. \& Yang, S., 2018, 'Generation-Z enters the advertising workplace: Expectations through a gendered lens', Journal of Advertising Education 22(1), 7-22. https://doi.org/10.1177/1098048218768595

Isa, R., Emuze, F., Das, D. \& Awuzie, B.O., 2018, 'Modeling a transformational route to infrastructure sustainability in South Africa', Built Environment Project and Asse Management 8(2), 147-159. https://doi.org/10.1108/BEPAM-11-2016-0070

James, K., 2015, 'Leadership special interest group: What is leadership?', Canadian Oncology Nursing Journal 25(1), 114-115.

Javidan, M., Bullough, A. \& Dibble, R., 2016, 'Mind the gap: Gender differences in global leadership self-efficacies', Academy of Management Perspectives 30(1) 59-73. https://doi.org/10.5465/amp.2015.0035

Jogulu, U.D. \& Wood, G.J., 2008, 'A cross-cultural study into peer evaluations of women's leadership effectiveness', Leadership and Organization Development Journal 29(7), 600-616. https://doi.org/10.1108/01437730810906344

Judge, T.A., Bono, J.E., Ilies, R. \& Gerhardt, M.W., 2002, 'Personality and leadership A qualitative and quantitative review', Journal of Applied Psychology 87(4), 765-780. https://doi.org/10.1037//0021-9010.87.4.765

Judge, T.A. \& Piccolo, R.F., 2004, 'Transformational and transactional leadership: A meta-analytic test of their relative validity', Journal of Applied Psychology 89(5) 755-768. https://doi.org/10.1037/0021-9010.89.5.755

Kaiser, R.B. \& Wallace, W.T., 2016, 'Gender bias and substantive differences in ratings of leadership behaviour: Towards a new narrative', Consulting Psychology Journal: Practice and Research 68(1), 72-98. https://doi.org/10.1037/cpb0000059

Kroon, B., Van Woerkom, M. \& Menting, C., 2017, 'Mindfulness as substitute for transformational leadership', Journal of Managerial Psychology 32(4), 284-297. https://doi.org/10.1108/JMP-07-2016-0223

Ladzani, W., Smith, N. \& Pretorius, L., 2012, 'Using leadership and strategic planning functions to improve management performance: The progress made by small, medium and micro enterprises (SMMEs) in the province of Gauteng, South Africa', African Journal of Business Management 6(11), 3988-3999. https://doi.org/ 10.5897/AJBM11.1015
Lai, L., 2011, Transformational-transactional leadership theory, viewed 03 April 2018, from https://www.academia.edu/11691701/Transformational-Transactional Leadership Theory.

Lidija, P.I., Kiril, P., Iliev, A.J. \& Shopova, M.M., 2017, 'Establishing balance between professional and private life of generation Z', Research in Physical Education, Sport and Health 6(1), 3-9.

Lopez-Zafra, E., Garcia-Retamero, R. \& Martos, M.P.B., 2012, 'The relationship between transformational leadership and emotional intelligence from a gendered approach', The Psychological Record 62(1), 97-114. https://doi.org/10.1007/ BF03395790

Mary, N.L., 2005, 'Transformational leadership in human service organisations', Administration in Social Work 29(2), 105-118. https://doi.org/10.1300/J147v 29n02 07

Matsuo, M., 2012, 'Leadership of learning and reflective practice: An exploratory study of nursing managers', Management Learning 43(5), 609-623. https://do org/10.1177/1350507612440413

McDowell, J., Huang, Y.K. \& Caza, A., 2018, 'Does identity matter? An investigation of the effects of authentic leadership on student-athletes' psychological capital and engagement', Journal of Sport Management 32(3), 227-242. https://doi.org/ $10.1123 /$ jsm.2017-0241

Mittal, R., 2015, 'Charismatic and transformational leadership styles: A cross-cultura perspective', International Journal of Business and Management 10(3), 26-33. https://doi.org/10.5539/ijbm.v10n3p26

Montuori, A. \& Donenelly, G., 2017, Transformative leadership, 1st edn., p.4, Springer International Publishing, San Francisco.

Munyaka, S.A., Boshoff, A.B., Pietersen, J. \& Snelgar, R., 2017, 'The relationships between authentic leadership, psychological capital, psychological climate, team commitment and intention to quit', SA Journal of Industrial Psychology 43(0), 1-11. https://doi.org/10.4102/sajip.v43i0.1430

Nascimento, D.L.M., Alencastro, V., Quelhas, O.L.G., Caiado, R.G.G., Garza-Reyes, J.A., Rocha-Lona, L. et al., 2019, 'Exploring industry 4.0 technologies to enable circular economy practices in a manufacturing context: A business model proposal', Journal of Manufacturing Technology Management 30(3), 607-627. https://doi. org/10.1108/JMTM-03-2018-0071

Pallant, J., 2016, SPSS survival manual: A step by step guide to data analysis using IBM SPSS, 6th edn., McGraw-Hill, London, United Kingdom.

Rahman, A., 2016, 'Organizational strategies and innovative leadership management', International Journal of Business and Management 11(10), 206-223. https://doi. org/10.5539/ijbm.v11n10p206

Ramachandiran, M. \& Dhanapal, S., 2018, 'Academic stress among university students: A quantitative study of generation $Y$ and Z's perception', Pertanika Journal of Social Sciences \& Humanities 26(3), 2115-2128.

Rosenberg, E., Lotz-Sisitka, H.B. \& Ramsarup, P., 2018, 'The green economy learning assessment South Africa: Lessons for higher education, skills and work-based learning', Higher Education, Skills and Work-based Learning 8(3), 243-258. https://doi.org/10.1108/HESWBL-03-2018-0041

Scheepers, C.B., Douman, A. \& Moodley, P., 2018, 'Sponsorship and social identity in advancement of woman leaders in South Africa', Gender in Management: An International Journal 33(6), 466-498. https://doi.org/10.1108/GM-062017-0076

Schyns, B., Tymon, A., Kiefer, T. \& Kerschreiter, R., 2012, 'New ways to leadership seve paints a thousand words', Management Learning $0(0)$ 1-14. https://doi.org/10.1177/1350507612456499

Sczesny, S., Bosak, J., Neff, D. \& Schyns, B., 2004, 'Gender stereotypes and the attribution of leadership traits: A cross-cultural comparison', Sex Roles 51(11/12) 631-645. https://doi.org/10.1007/s11199-004-0715-0

Shaked, H., Gross, Z. \& Glanz, J., 2019, 'Between Venus and Mars: Sources of gender differences in instructional leadership', Educational Management Administration \& Leadership 47(2), 291-309. https://doi.org/10.1177/17411 43217728086

Tung, F., 2016, 'Does transformational, ambidextrous, transactional leadership promote employee creativity? Mediating effects of empowerment and promotion focus', International Journal of Manpower 37(8), 1250-1263. https://doi.org/ 10.1108/IJM-09-2014-0177

University of Pretoria, 2018, Course notes for NME 704: Research methodology, Department of Business Management, University of Pretoria, Pretoria.

Van Jaarsveld, L., Mentz, P.J. \& Ellis, S., 2019, 'Implementing the multifactor leadership questionnaire ( $\mathrm{mlq}$ ) in a challenging context: Results from a large-scale quantitative study', International Journal of Educational Management 33(4), 604-613. https:// doi.org/10.1108/IJEM-02-2018-0041

Winston, B.E. \& Patterson, K., 2006, 'An integrative definition of leadership', International Journal of Leadership Studies $1(2), 6-66$

Xiaoxia, P. \& Jing, W., 2006, 'Transformational leadership vs transactional leadership: The influence of gender and culture on leadership styles of SMEs in China and Sweden', 1-113. Unpublished master's dissertation, Kristianstad University, Kristianstad, viewed 14 April 2018, from https://www.diva-portal.org/smash/get/ diva2:230525/FULLTEXT01.pdf. 